CABRAL, Astrid. Intramuros. 2a Ed. Manaus: Editora Valer, 2011, 118 p.

\title{
OS CÓDIGOS AMAZÔNICOS DA POESIA "INTRAMUROS", DE ASTRID CABRAL
}

THE AMAZON CODES OF THE POETRY “INTRAMUROS”, BY ASTRID CABRAL

\author{
Douglas Rosa da Silva ${ }^{1}$
}

Como se constrói a face da expressão literária amazônica na poesia? É possível afirmar que na diversidade das poéticas do presente, uma dicção amazônica também se estabelece como possibilidade textual? A coletânea de poemas Intramuros, de Astrid Cabral, parece viabilizar alguns retornos para as questões levantadas, no entanto, essas leituras abandonam perspectivas definitivas e totalizantes, porque a partir delas novas dúvidas são suscitadas. Longe do papel determinante que a natureza assume nas obras naturalistas, a obra Intramuros edifica poemas em que o ambiente regional se coloca como a matéria-prima, a medula da linguagem. Ainda assim, a coletânea não se restringe a ser um mero exercício de representação daquilo que circunda a zona familiar, pois a representação, em Intramuros, é justamente a ferramenta que o sujeito poético utiliza para provocar o leitor.

Na poética astridiana, o retrato da Amazônia não aparece como um dado fixo ou um cenário em que as ações transcorrem; esses retratos são, sobretudo, dispositivos de visualidades múltiplas, disformes, móveis, nunca captadas completamente no ato da leitura. A obra, portanto, não se ocupa em configurar no mapa as especificidades de uma geografia ou de uma determinada região, mas apresenta, como principal objetivo, questionamentos constantes sobre as dinâmicas e as simbioses simbólicas que ocorrem na interioridade da vida cotidiana. É diante das investidas contra a demarcação de linhas divisórias que a expressão literária amazônica, curiosamente, mostra a sua força na poesia de Astrid Cabral. Isso porque que a primeira designação dada a todo e qualquer símbolo da natureza mostra-se débil no desenrolar dos poemas, como se a voz lírica simulasse, o tempo todo, uma perturbação com a falta de limites entre o que está dentro (o universo alterado, construído) e o que está fora (o universo orgânico):

\footnotetext{
${ }^{1}$ Doutorando no PPG em Letras da UFRGS.
} 
"que fazem aqui as laranjas/emigradas das árvores?/Bem estariam nos galhos/escuros da madrugada/em vez do agressivo prato/de onde me encaram furtivas". (CABRAL, 2011, p. 21).

Em Intramuros, ou por trás dos muros, a poesia eleva as tensões das coexistências entre o que é aparentemente natural e o que é pretensamente inventado, e a enunciação poética realiza essa ação por meio de uma "poesia sem telha e sem grades", como relata o crítico literário Fausto Cunha (2011, p. 16), no prefácio do livro. Ainda que a obra de Astrid encene certo clima "doméstico", a voz lírica entrega, no jogo da leitura, que o abrigo dos sentidos pode ser sempre desestabilizado, e que os muros entre os universos são fictícios, pois as textualidades poéticas deixam explícito que uma das faces da expressão literária amazônica trata de restabelecer e desalinhar os lugares e os objetos resultantes da intervenção humana. Por isso, as alusões nos poemas frequentemente correspondem a um fenômeno da natureza e/ou a um código regional, e o eu-lírico captura o momento em que as demarcações entre o universal e o particular são diluídas: “A pedra do Rio Verde/gera um rio na minha casa/fluindo subterrâneo/sob o tapete da sala//[..]//A pedra do Rio Verde/quebra a madeira das portas/e na mãe terra, de volta,/me recoloca liberta”. (CABRAL, 2011, p. 26).

Os códigos da linguagem literária se entremeiam nesses espaços privados e configurados, e exigem uma releitura, uma nova roupagem, entendem-se à volta de utensílios, móveis, monumentos, prédios e casas executando uma simbiose com esse mundo de fora, decorrente das criações humanas. Por isso, a supressão das barreiras dos ambientes supostamente fragmentados é a atividade realizada com maior recorrência pelo sujeito poético em Intramuros:



Desde 1963, nos contos do livro Alameda, primeira publicação da autora, Astrid Cabral tem demonstrado uma trajetória consistente e vigorosa na Literatura Brasileira. Natural de Manaus, no Amazonas, Astrid estabeleceu desde muito cedo uma relação afeiçoada com as palavras. Mais tarde, essa aproximação com o mundo literário desencadeia episódios que marcam circunstâncias particulares na vida da autora - bem como iluminam pontos significativos de sua produção. O convívio desde a meninice com a poesia, seja pelos textos 
apresentados no jardim de infância ou aqueles advindos do hábito de leitura da família, ajusta e concebe a imagem de uma ambiência amazônica envolta em significados que se opõem aos efêmeros deslumbramentos do excursionista ou do viajante que visita aquela região. Se a poesia atravessa a vida da autora, então, do mesmo modo, esses atravessamentos também alteram a forma na qual a poeta lida e avista o espaço em que vive. Esses retratos de uma Amazônia desconstruída e permanentemente interpelada por meio do texto poético são fundamentais para pensar a produção astridiana, especialmente, para pensar os escritos reunidos em Intramuros. No livro, os clichês e as expectativas do que venha a ser uma poética amazônica são superados, e Astrid revela, com erudição e destreza no uso das palavras, que possui uma marca própria no terreno da poesia brasileira. A leitura dos poemas mostra uma autora madura, experiente, conhecedora das tendências diversas, e que ainda assim consegue imprimir, sem hesitar, uma visão distintiva e aprimorada dos fatos abrangidos pelo fenômeno poético.

O deslocamento constante também tem um papel considerável na trajetória pessoal e bibliográfica de Astrid Cabral. Ainda na juventude, as viagens para outras cidades do país foram contínuas, e aos dezoito anos, a poeta embarca para o Rio de Janeiro para ingressar no curso de Letras Neolatinas da extinta Faculdade Nacional de Filosofia (instituição que hoje é a UFRJ). Na vida adulta, outra grande mudança: o matrimônio com o também poeta Afonso Félix de Sousa e a chegada da maternidade foram acompanhadas pela mudança de Astrid para Brasília, já que a autora foi convocada para exercer a atividade docente na recém-inaugurada UnB. Apesar disso, o contato com o contexto amazonense nunca foi encerrado pela poeta, pois nessa época Astrid ainda cultivava e mantinha os diversos vínculos (com a imprensa, com os amigos, com os movimentos culturais e literários, etc.) de sua região. Essa extensão dos vínculos com o seu lugar de origem (que viria, após a aposentadoria da autora, também se tornar um lugar de moradia alternativa) garante para a produção astridiana escritos em que as paisagens parecem deslocadas, fora de lugar, porque são imagens que retomam constantemente um ponto de assimilação com os códigos amazônicos. Ocorre, nessa operação da poesia, um duplo deslocamento: primeiro, a expressão literária amazônica vai se ocupar de discorrer sobre objetos fora do seu meio autêntico, ou do seu habitat natural; e segundo, a diversidade de paisagens (das grandes metrópoles, rurais, não-amazônicas, etc.) são transmutadas por meio de uma dicção poética que injeta o signo da diferença naquilo que está consolidado cotidianamente e paisagisticamente. Em Intramuros, os poemas estão marcados por esse duplo deslocamento. Ou o sujeito poético se volta para elementos que integram a informalidade dos dias, transformando-os, como nos poemas "Piscina", "Ovo Estrelado", "Comunhão" e "Metamorfose", ou a paisagem externa e distante, fora do eixo regional, será remodelada e 
redimensionada no ato poético, conforme ilustrado nos poemas "Postais Sul-Americanos", "Postais de Paris", e "Roma sob pólen".

No Amazonas, Astrid Cabral participou ativamente de propostas de revitalização e fortalecimento da literatura de expressão amazonense. Mesmo que a poeta, ainda hoje, se ocupe em promover a literatura produzida no norte do Brasil, foi com o movimento chamado "Clube da Madrugada", originado em 1954, que a autora se projetou com ainda mais força como uma voz importante no meio literário amazônico. A iniciativa inédita na cultura local vinha como um desdobramento tardio das demandas modernistas mobilizadas principalmente no sudeste do país. No verbete "Clube da Madrugada", da Enciclopédia de Literatura Brasileira, Afrânio Coutinho e José Galante Sousa (2001), a partir de uma análise histórica e cultural da associação, definem o clube como parte de um momento fulcral na história da literatura amazonense. A contribuição e a participação de Astrid no "Clube da Madrugada" foram definitivas para circunscrever algumas das particularidades e traços que permeiam a produção literária de autores da região até hoje. A poeta, conforme apontam Sampaio e Silveira (2015), foi a única voz feminina a participar do movimento. Os objetivos desse empreendimento representativo na história da literatura e da cultura amazonense ainda perseveram na produção da autora, e em Intramuros, isso não é diferente. A necessidade de um novo fôlego para o estilo poético aliada a um distanciamento dos modos eruditos e convencionais do fazer literário aparece como um atributo do livro. As formas mistas, por vezes experimentais de conceber o poema, perpassam as páginas da coletânea, deixando a sensação de que o conjunto de textos poéticos ali reunido não intenta ser uma unidade coerente e harmônica, mas tem o objetivo de se estabelecer como um desafio convidativo aos olhos dos leitores que dele se aproximam.

É incitando diferentes possibilidades que Intramuros chamou a atenção da crítica especializada já na data de sua primeira publicação. A obra angariou o importante Prêmio Nacional de Poesia Helena Kolody², e aparece como um livro referência no conjunto bibliográfico da poeta ${ }^{3}$. Publicado originalmente em 1998, a segunda edição de Intramuros foi complementada com vinte e cinco novos poemas, e republicada, em nova e segunda edição, em 2011. Esse acréscimo de poemas inéditos bem como a revisão dos textos integrantes da primeira edição do livro modificaram e ampliaram, de certo modo, as questões desencadeadas na coletânea. Organizada em seções de núcleo temático, Intramuros divide-se em três partes:

\footnotetext{
${ }^{2}$ A autora conquistou esse prêmio uma única vez, em 1998. A premiação é uma das mais importantes na história da Literatura Nacional, e faz homenagem a poeta paranaense Helena Kolody. Atualmente, o prêmio Helena Kolody é um desdobramento do Prêmio Paraná de Literatura, e nomeia a categoria "livros de poesia".

${ }^{3}$ Também são obras escritas por Astrid Cabral: Ponto de Cruz, de 1979, Torna-Viagem, de 1981, Lição de Alice, de 1986, Visgo da Terra, de 1986, Ante-sala, de 2007, Palavra na Berlinda, de 2011, e Infância em franjas, de 2014.
} 
poemas de "Intramuros", poemas de "Jaula" e poemas de "Extramuros". A organização e a disposição das seções da coletânea, no plano das imagens, apontam para uma interessante construção alegórica, pois entre o universo íntimo abarcado pelos textos de "Intramuros" e o universo público exposto nas modulações poéticas de "Extramuros", o leitor se depara com os escritos da seção "Jaula", que colocam os animais no liame (ou no trânsito) entre o particular e o comum, entre o que é distintivo e o que é banal. O fio que atravessa e interliga as três seções da coletânea sustenta uma poesia "comprometida com o visgo da terra", conforme relata o escritor Elson Farias, na orelha do livro. Como um todo, Intramuros também é uma obra para "aquelas companheiras/que põem a mão na massa/do pão e da palavra" ${ }^{4}$, dado que a voz que fala no conjunto lírico registra o que há nas entranhas do ambiente regional, e vasculha, de igual modo, os objetos corriqueiros integrantes da vida ordinária - e tudo isso é feito sob a indelével ótica do feminino.

$\mathrm{Na}$ primeira parte da obra, intitulada "Intramuros", o eu-lírico discorre sobre os acontecimentos dissonantes e inesperados que invadem as cerimônias do dia. Por isso, elementos como "xícaras", “armário", “jornais", “azulejo da cozinha", "telhas" e "tapete da sala" aparecem de forma assídua nos poemas iniciais do livro, ajudando a criar episódios envoltos em certa familiaridade, como se o leitor fizesse parte dessa rotina doméstica dada “intramuros". No entanto, em cada um desses escritos, há uma quebra da expectativa, pois aquele que se aproxima das imagens formadas no poema logo nota que a familiaridade é fantasiosa, e que esses ambientes, supostamente seguros, estão infiltrados de uma força desestabilizante provinda dos códigos amazônicos vivenciados e imaginados pela poeta. A primeira estrofe do poema "Ventiladores" exemplifica essa quebra da expectativa e ilustra o instaurar de um componente regional desdobrado por meio de um objeto comum, o ventilador. Ao contemplar a função dessa peça, o eu-lírico a reelabora, inserindo esse objeto em outro tempo, em outro lugar: "1. Múltiplas asas brancas/voam não voam revoam/no céu não céu da gaiola" e a voz poética emenda, finalizando: "Servil, essa ave cativa/longe de auroras e nuvens/nostálgica imita a brisa" (CABRAL, 2011, p. 43).

Em "Jaula", segunda parte de Intramuros, todos os textos integrantes da seção trazem nomes de animais, com exceção do poema que fecha a segunda parte da obra, intitulado "Reordenação do mundo". É possível depreender, a partir da leitura de "Reordenação do mundo", que os textos anteriores desempenham a função de restauradores e mediadores da interdependência entre o indivíduo e a sua própria condição de animal. A escritura poética

\footnotetext{
${ }^{4}$ Epígrafe de abertura de Intramuros, escritos pela própria Astrid.
} 
escancara a selvageria dos modos civilizados, e novamente, as fronteiras entre o ser domesticado e o ser da natureza parecem borradas, fundidas - o leitor navega nessa instigante intersecção entre a sensibilidade animal e a brutalidade humana, e vice-versa. Embora conflituosa, o eu-lírico reconhece, em tom de confidência, sobre essa relação: "À medida que envelheço/as sete cabeças do bicho/corto. Enfim o reconheço/íntimo de mim, meu próximo./À medida que envelheço/conquisto-lhe o segredo/Vejo a morte iniciação/À viagem pelo avesso.” (CABRAL, 2011, p. 60). O atrito desencadeia uma proximidade da voz poética com as suas faces indomesticadas e silvestres. Por conseguinte, o indivíduo moderno encontra nessas “inéditas e fantásticas/bestas que infectam-infestam” (CABRAL, 2011, p. 62) uma ponderação acerca dos aprisionamentos do que é humano e do que é animal. A poesia, nessa segunda parte de Intramuros, desperta o leitor para que ele possa enxergar tanto a si quanto o animal para além das "Jaulas".

A terceira e última parte do livro, intitulada "Extramuros", exibe um eu-lírico viajante, descobridor de outras paisagens, que agora se ocupa em elaborar reflexões acerca desses novos cenários explorados e percorridos. Ao mesmo tempo, as suas andanças "extramuros" - todas distantes da sua atmosfera regional - evocam um ar saudosista, de encantamento provisório, ocasionalmente insatisfeito. O poema que abre a seção, "Rastros do Paraíso", deixa evidente o descontentamento da voz lírica com a paisagem de São Paulo, pois na ânsia em ver a originalidade do habitat natural (ou aquilo que julga ser o "paraíso"), esse sujeito poético se frustra ao perceber que das "terras autênticas" só sobraram os nomes de alguns bairros e cidades (todos eles nomes de origem indígena): Itanhaém, Itacoatiara,/ Anhangabaú, Jabaquara.../Rastros do paraíso./Mas e os pássaros e os peixes/ubi sunt?/Mas as flores e as frutas/ubi sunt?/Mas as cobras e feras/ubi sunt?/Os donos do paraíso partiram./Sobrou a herança dos nomes: [...]”. (CABRAL, 2011, p. 71).

Pode-se afirmar, desse modo, que os três núcleos temáticos que constituem a obra lidam e trabalham com o dissolver dos limites e com o rompimento das expectativas de diferentes modos, sendo que todas essas operações poéticas parecem atreladas a uma promoção dos códigos amazônicos, a saber: a) na primeira seção, "Intramuros", as cerimônias do dia são desarrumadas por elementos orgânicos e/ou naturais, que invadem o ambiente familiar, fundindo-se nele; b) na segunda seção, "Jaula", o sujeito civilizado que não se reconhece no animal vê-se frustrado, vencido, e no fim, ambos se rendem a uma inevitável junção; c) na última seção, "Extramuros”, a paisagem descoberta não contenta completamente o eu-lírico andante, pois esses paraísos não apresentam correlação com elementos da sua regionalidade. 
Portanto, a voz poética passa a interpelar esses cenários outros, desfazendo-os, sob um evidente signo da falta.

Em síntese, destaca-se que em Intramuros, para além das já consolidadas poéticas de apresentação do in-visível, eleva a presença de uma poesia que aponta que os limites são apenas invencionices - pois o texto poético também é da ordem do vai-e-vem, do deslocamento irrestrito. A coletânea assenta essa vontade lírica de levar o leitor para atravessar e dialogar com as vedações e com os muros geográficos e da realidade, e coloca em cena a importância dos códigos amazônicos como um meio de refinar a sensibilidade humana. Esses códigos, mais do que provocar a lembrança de onde viemos, não nos deixam esquecer de quem nós somos, especialmente em tempos em que os desflorestamentos diversos representam um risco à memória e a história. Na contemporaneidade, os códigos amazônicos da poesia figuram como um alarme de incêndio ampliado na Literatura. A lição de Intramuros, de Astrid Cabral, propõe retirar as barreiras entre o nacional e o regional, e nesse espaço em que todos/as se reúnem, a voz poética fica livre para denunciar, relembrando: "A sorte é que ainda me lembro,/ainda me lembro de como era antes". (CABRAL, 2011, p. 73).

\section{REFERÊNCIAS}

CABRAL, Astrid. Antologia pessoal: Astrid Cabral. Brasília: Theasurus Editora, 2008.

COUTINHO, Afrânio; SOUSA, J. Galante. Enciclopédia de literatura brasileira. São Paulo: Global, 2001.

SAMPAIO, Enderson de Souza; SILVEIRA, Ederson Luís. Astrid Cabral e a literatura amazonense: sobre escritas e exterioridades nas poéticas da memória. Interdisciplinar, n. 13, v. 01, 2015, p. 76-80.

Recebido em 02/08/2020. Aceito em 02/08/2020. 